\title{
Prevalence of Cytomegalovirus Infection in Patients With Ulcerative Colitis by Using PCR Technique
}

\author{
Sahar Mehrabani-Khasraghi, ${ }^{1, *}$ Mitra Ameli, ${ }^{2}$ Farzad Khalily, ${ }^{3}$ and Masood Ghane ${ }^{1}$ \\ ${ }^{1}$ Department of Microbiology, Tonekabon Branch, Islamic Azad University, Tonekabon, IR Iran \\ ${ }^{2}$ Department of Medicine, Tonekabon Branch, Islamic Azad University, Tonekabon, IR Iran \\ ${ }^{3}$ Gastroenterology and Hepatology Research Center, Karaj University of Medical Sciences, Karaj, IR Iran \\ *Corresponding author: Sahar Mehrabani-Khasraghi, Department of Microbiology, Tonekabon Branch, Islamic Azad University, Tonekabon, IR Iran. E-mail: saharmehrabani1@gmail.com
}

Received 2014 February 3; Accepted 2014 December 31.

\begin{abstract}
Background:Ulcerative colitis is one type of inflammatory bowel disease.

Objectives: The aim of this study was to investigate the prevalence of cytomegalovirus in patients with ulcerative colitis in comparison with healthy subjects by using PCR technique.

Patients and Methods: In this analytical case-control study, 5 patients with ulcerative colitis and 30 patients without malignancy as controls were selected. Biopsy specimens were frozen under sterile conditions at $-20^{\circ} \mathrm{C}$. After DNA extraction, analysis of polymerase chain reaction (PCR) to detect CMV DNA in tissue samples was performed. Statistical analysis was performed with $\chi 2$ test.

Results: CMV DNA was found in $80 \%$ of ulcerative colitis samples ( 4 of 5) and $30 \%$ of the non-malignant control group ( 9 of 30 ). Statistical analysis showed significant association between the prevalence of CMV and incidence ulcerative colitis in comparison with the control group $(\mathrm{P}=0.03)$.

Conclusions: The results of the present study has shown ulcerative colitis patients have a predisposition to CMV infection as compared to healthy individuals, but the etiologic link between ulcerative colitis and CMV infection needs to be studied.
\end{abstract}

Keywords: Ulcerative colitis, Cytomegalovirus, Polymerase chain reaction

\section{Background}

Cytomegalovirus (CMV) is a member of the herpesviradae family which also includes Epstein-Barr virus, herpes simplex virus, varicella-zoster virus, and herpes virus 6 , 7 , and 8 [1]. The virus is transmitted through close personal contact with body fluids, including blood, urine and saliva, also cytomegalovirus infection can occur in immunocompetent individuals, but it most frequently occurs in immunocompromised patients such as recipients of organ transplants, patients undergoing hemodialysis, patients receiving immunosuppressive drugs, and patients with acquired immune deficiency syndrome [2]. Cytomegalovirus infection is ubiquitous in developed nations, with laboratory evidence of prior infection in $40 \%-70 \%$ of the general adult population $[3,4]$. Inflammatory bowel disease (IBD) represents a group of idiopathic chronic inflammatory intestinal conditions. The two main disease categories the covers are Crohn's disease (CD) and ulcerative colitis (UC) with both overlapping and distinct clinical and pathological features. In recent years, cases of IBD associated with cytomegalovirus infection have occasionally been reported [5, 6]. In these patients, cytomegalovirus has been recognized in colonoscopy biopsy specimens obtained during evalua- tion and management of inflammatory bowel disease or diagnosed after pathologic examination of colon. Some reports have also assumed a triggering role of CMV infection in the onset or the worsening of the IBD or even in the development of malignancy in the colon [7, 8]. However, prospective studies examining prevalence of CMV genome in patients with IBD in comparison with a control population are limited. CMV infection in IBD patients often makes clinical diagnosis and treatment complex. de Saussure et al. treated 3 CMV-positive IBD cases with antiviral therapy, and only 1 patient got remission [9]. Kandiel and Lashner used antiviral drugs for the treatment of CMV positive colitis, and achieved a remission rate of $67 \%-100 \%[10]$.

\section{Objectives}

Give the importance of inflammatory bowel disease as the unknown etiology and detection of an infectious agent in these patients might have important implications in treatment and prevention, the present study to investigate the prevalence of CMV in patients with ulcerative colitis in comparison with healthy subjects by using PCR technique conducted.

Copyright (C) 2015, Zahedan University of Medical Sciences. This is an open-access article distributed under the terms of the Creative Commons Attribution-NonCommercial 4.0 International License (http://creativecommons.org/licenses/by-nc/4.0/) which permits copy and redistribute the material just in noncommercial usages, provided the original work is properly cited. 


\section{Patients and Methods}

\subsection{Patients}

In this analytical case-control study, informed consent was received from all patients admitted to the Endoscopy clinic of Toos and Firoozgar hospital in Tehran, Iran, between January 2013 and May 2013. In this study five patients with ulcerative colitis and thirty patients without malignancy as controls were selected. Sampling was performed by endoscopic biopsy operation. All collected tissues were kept frozen under $-20^{\circ} \mathrm{C}$ until analysis.

\subsection{DNA Extraction}

The DNA was extracted using the KiaSpin $₫$ Tissue kit (Kiagen CA, Iran) according to the manufacture's instructions. In order to determine the concentration of the sample absorbance at a wavelength to $260 \mathrm{~nm}$ was performed by biophotometer system (Eppendorf, Germany). In addition, to determine the purity of the sample wavelength of 280/260 and 230/260 was also examined.

\section{3. $P C R$}

In order to determine the quality of the extracted DNA, PCR amplification of the gene for human $\beta$-globulin was carried out (Table 1) [11]. The mixture reaction PCR for a reaction volume of $20 \mu \mathrm{L}$ containing $10 \mu \mathrm{L}$ prime taq premix (2x) (Kiagen CA, Iran), $3 \mu \mathrm{L}$ of sterile distilled water, $1 \mu \mathrm{L}$ of forward and rivers primers (TAG Compenhagen, Denmark), and $5 \mu \mathrm{L}$ of DNA template. The PCR reaction was carried out in accordance with the schedule of time and temperature. As first denaturation $95^{\circ} \mathrm{C}$ for 5 minutes, then 35 cycles of $95^{\circ} \mathrm{C}$ for 50 seconds, $55^{\circ} \mathrm{C}$ for 45 seconds, $72^{\circ} \mathrm{C}$ for 40 seconds and finally $72^{\circ} \mathrm{C}$ for 5 minutes final elongation was performed.

In order to reproduce the CMV genome of samples was performed using specific primers (Table 1) [11]. The mixture reaction PCR for a reaction volume of $20 \mu \mathrm{L}$ containing $10 \mu \mathrm{L}$ prime taq premix (2x) (Kiagen CA, Iran), $3 \mu \mathrm{L}$ of sterile distilled water, $1 \mu \mathrm{L}$ of forward and rivers primers (TAG Compenhagen, Denmark), and $5 \mu \mathrm{L}$ of DNA template. The PCR reaction was carried out in accordance with the schedule of time and temperature. As first denaturation $95^{\circ} \mathrm{C}$ for $5 \mathrm{~min}$, then 35 cycles of $95^{\circ} \mathrm{C}$ for 50 seconds, $60^{\circ} \mathrm{C}$ for 45 seconds, $72^{\circ} \mathrm{C}$ for 40 seconds and finally $72^{\circ} \mathrm{C}$ for 5 min final elongation was performed. Then $5 \mu \mathrm{L}$ of the PCR product on a $1.5 \%$ agarose gel was taken.

\subsection{Statistical Analysis}

Statistical analysis were performed using the SPSS-20 (SPSS, Inc., Chicago, USA) software package. The relationship between the prevalence of CMV and occurrence of ulcerative colitis and also compared with control group tissue samples were analyzed using the t-test and $\chi^{2}$ test. Statistical significance was accepted at the 5 percent level.

\section{Results}

In patients with ulcerative colitis, CMV DNA was found in $80 \%$ of samples (4 of 5). CMV DNA was found in 30\% of patients in the control group of non-malignant ( 9 of 30). Statistical analysis showed significant association between the prevalence of CMV and incidence ulcerative colitis in comparison with the control group $(\mathrm{P}=0.03)$.

The results showed that the highest prevalence of CMV in patients with ulcerative colitis older than 55 years (60\%) and in non-malignant control group in two age groups of $35-55$ years (13.3\%) and under 35 years (13.3\%). In terms of gender, the highest prevalence of CMV in patients with ulcerative colitis in both of two gender women (40\%) and men (40\%), and in non-malignant control group women (16.6\%) have been observed.

Statistical analysis showed no significant association between the prevalence of CMV, age group and gender, in patients with ulcerative colitis in comparison with control group.

In all tissue samples $106 \mathrm{bp}$ band that represents the amplification of human $\beta$-globulin gene observed (Figure 1). Due to the quality and reliability of DNA extracted, PCR analysis with CMV specific primers was performed; $167 \mathrm{bp}$ bands that represent the replication is observed (Figure 2 ).

\begin{tabular}{ccc}
\hline \multicolumn{3}{l}{ Table 1. Primers Sequences and Base Pair (bp) Length } \\
\hline Primer & \multicolumn{1}{c}{ Sequence } & Size, bp \\
\hline b 2 & & 106 \\
F & 5' TCCAACATCAACATCTTGGT 3' \\
R & 5' TCCCCCAAATTCTAAGCAGA 3' \\
CMV & & \\
F & 5' GTCACCAAGGCCACGACGTT3' & \\
R & 5' TCTGCCAGGACATCTTTCTC 3' \\
\hline
\end{tabular}

Figure 1. PCR Analysis of $\beta$-globulin

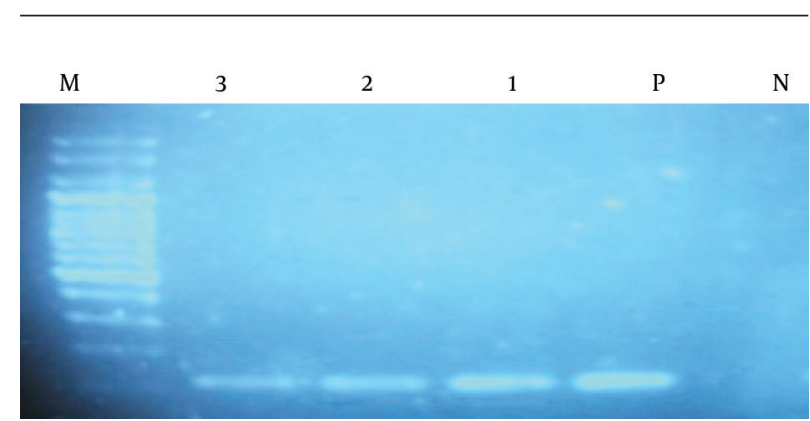

DNA extracted from tissue samples was amplified for $\beta$-globulin gene using primers described in methods.Amplification yielded a band of $106 \mathrm{bp}$. As positive control (P), human DNA from fresh tissue was used; as negative control (N), PCR master mix without DNA was used. Clinical samples, lanes 1 - 3. DNA molecular weight marker, $\mathrm{M}$. 
Figure 2. PCR Analysis for the Detection of Cytomegalovirus (CMV) From Tissue Samples

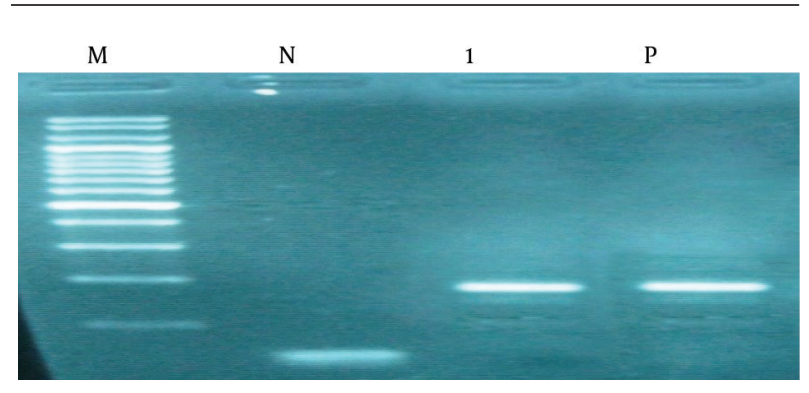

DNA extracted from tissues was amplified with specific primers. Amplification of fragment yielded a band of $167 \mathrm{bp}$. Positive control (P); negative control (N); clinical sample, lanes 1; DNA molecular weight marker (M).

\section{Discussion}

In this study, we investigated ulcerative colitis and nonmalignant tissues for the presence of CMV DNA by PCR method. Results showed that the prevalence of viral DNA in specimens of ulcerative colitis $80 \%$ and $30 \%$ in non-malignant control group.

Cytomegalovirus is an opportunistic pathogenic microorganism. During recent years, a clear association between complicated courses of ulcerative colitis and the presence of cytomegalovirus has been established. The exact pathogenic role of cytomegalovirus in these patients remains unclear despite a great number of published reports. Powell et al. [12] first reported the association of cytomegalovirus with ulcerative colitis in 1961. CMV infection in ulcerative colitis patients, especially in those who are immune-compromised by steroid therapy, can produce severe systemic disease and often leads to colectomy, but the coincidental diagnosis of UC and CMV colitis has also been reported [13-16]. However, the importance of CMV as an exacerbating factor of UC is neglected by many clinicians. PCR has emerged as the most sensitive laboratorial method for diagnosis of viral infection including that with CMV [15]. In the current study has shown the presence of CMV sequences in ulcerative colitis tissues and non-malignant by PCR method reflects the ability of the virus to infect of the different colon cells. These results suggested a possible causative association between CMV and ulcerative colitis. In the study by Dimitroulia et al. [4] in the intestinal tissue CMV genome was detected in $32.9 \%$ of the IBD patients and only in $2.4 \%$ of the controls, also a significant association was detected between CMV intestinal infection and either ulcerative colitis or Crohn's disease, although the association was even stronger for patients with ulcerative colitis. Hommes et al. [14] evaluated the pathogenicity of cytomegalovirus in inflammatory bowel disease; their results showed CMV causes significant clinical morbidity in IBD patients. Kishore et al. [15] investigated infection with cytomegalovirus in patients with inflammatory bowel disease, sixty-three patients with IBD (both UC and CD) were selected, results showed CMV infection in patients with IBD may be common, this has definite clinical significance and therefore should not be ignored. Although our results confirmed the results of Dimitroulia et al. [4], Hommes et al. [14] and Kishore et al. [15] indicating that there is association between CMV infection and progression of inflammatory bowel disease. However, in other studies, no evidence of a direct association between inflammatory bowel disease and CMV infection was found $[16,17]$. In the study by Yi et al. [16] on the prevalence and risk factors of cytomegalovirus infection in inflammatory bowel disease in Wuhan, central China, 226 IBD patients (189 ulcerative colitis and 37 patients with Crohn's disease) were selected, CMV DNA was detected by nested PCR, their results showed no risk factor was found to be significantly correlated with CMV infection in risk factors analysis. Also, Leveque et al. [17] found no relationship between CMV viral load and disease severity in patients with active IBD.

In conclusion, our observations, suggest that UC patients have a predisposition to CMV infection as compared to healthy individuals, but the etiologic link between UC and CMV infection needs to be studied.

\section{Acknowledgements}

This paper has been extracted from proposal No. 23796 (Performer: Sahar Mehrabani-Khasraghi). We would like to express thanks of Mr Shabani for his kind help with this project, and all patients who participated in the study.

\section{Footnotes}

Authors' Contribution:All authors had equal role in design, work, statistical analysis and manuscript writing. Funding/Support:Endoscopy clinic of Toos and Firoozgar hospitals in Tehran, Iran.

\section{References}

1. Taylor GH. Cytomegalovirus. Am Fam Physician. 2003;67(3):51924. [PubMed: 12588074]

2. Rafailidis PI, Mourtzoukou EG, Varbobitis IC, Falagas ME. Severe cytomegalovirus infection in apparently immunocompetent patients: a systematic review. Virol J. 2008;5:47. doi: 10.1186/1743422X-5-47. [PubMed:18371229]

3. Begos DG, Rappaport R, Jain D. Cytomegalovirus infection masquerading as an ulcerative colitis flare-up: case report and review of the literature. Yale J Biol Med.1996;69(4):323-8. [PubMed: 9273986]

4. Dimitroulia E, Spanakis N, Konstantinidou AE, Legakis NJ, Tsakris A. Frequent detection of cytomegalovirus in the intestine of patients with inflammatorybowel disease.Inflamm Bowel Dis. 2006;12(9):87984. doi:10.1097/01.mib.0000231576.11678.57. [PubMed:16954807]

5. Vega R, Bertran X, Menacho M, Domenech E, Moreno de Vega V, Hombrados $\mathrm{M}$, et al. Cytomegalovirus infection in patients with inflammatory bowel disease. Am J Gastroenterol. 1999;94(4):10536. doi:10.1111/j.1572-0241.1999.01013.x. [PubMed: 10201482]

6. Hamlin PJ, Shah MN, Scott N, Wyatt JI, Howdle PD. Systemic cytomegalovirus infection complicating ulcerative colitis: a case report and review of the literature. Postgrad Med J. 2004;80(942):233-5. [PubMed: 15082847]

7. Lortholary O, Perronne C, Leport J, Leport C, Vilde JL. Primary cytomegalovirus infection associated with the onset of ulcerative colitis. Eur J Clin Microbiol Infect Dis. 1993;12(7):570-2. [PubMed: 
8404926]

8. Shimada Y, Iiai T, Okamoto H, Suda T, Hatakeyama K, Honma T, et al. Toxic megacolon associated with cytomegalovirus infection in ulcerative colitis. J Gastroenterol. 2003;38(11):1107-8. doi: 10.1007/s00535-003-1217-5. [PubMed:14673733]

9. de Saussure P, Lavergne-Slove A, Mazeron MC, Alain S, Matuchansky C, Bouhnik Y. A prospective assessment of cytomegalovirus infection in active inflammatory bowel disease. Aliment Pharmacol Ther.2004;20(11-12):1323-7. doi:10.1111/j.1365-2036.2004.02273.x. [PubMed: 15606394]

10. Kandiel A, Lashner B. Cytomegalovirus colitis complicating inflammatory bowel disease. Am J Gastroenterol. 2006;101(12):285765. doi: 10.1111/j.1572-0241.2006.00869.x. [PubMed:17026558]

11. Zaravinos A, Bizakis J, Spandidos DA. Prevalence of human papilloma virus and human herpes virus types 1-7 in human nasa polyposis. J Med Virol. 2009;81(9):1613-9. doi: 10.1002/jmv.21534. [PubMed: 19626617]

12. Powell RD, Warner NE, Levine RS, Kirsner JB. Cytomegalic inclusion disease and ulcerative colitis. Am J Med. 1961;30(2):334-40. doi:10.1016/0002-9343(61)90105-x. [PubMed: 13737621]

13. Orvar K, Murray J, Carmen G, Conklin J. Cytomegalovirus infec- tion associated with onset of inflammatory bowel disease. Dig Dis Sci.1993;38(12):2307-10. [PubMed: 8261839]

14. Hommes DW, Sterringa G, van Deventer SI, Tytgat GN, Weel J. The pathogenicity of cytomegalovirus in inflammatory bowel disease: a systematic review and evidence-based recommendations for future research. Inflamm Bowel Dis. 2004;10(3):245-50. [PubMed: 15290919]

15. Kishore J, Ghoshal U, Ghoshal UC, Krishnani N, Kumar S, Singh $\mathrm{M}$, et al. Infection with cytomegalovirus in patients with inflammatory bowel disease: prevalence, clinical significance and outcome. J Med Microbiol. 2004;53(Pt 11):1155-60. doi: 10.1099| jmm.0.45629-0. [PubMed:15496396]

16. Yi F, Zhao J, Luckheeram RV, Lei Y, Wang C, Huang S, et al. The prevalence and risk factors of cytomegalovirus infection in inflammatory bowel disease in Wuhan, Central China. Virol J. 2013;10:43. doi:10.1186/1743-422X-10-43. [PubMed: 23374225]

17. Leveque N, Brixi-Benmansour H, Reig T, Renois F, Talmud D, Brodard V, et al. Low frequency of cytomegalovirus infection during exacerbations of inflammatory bowel diseases. J Med Virol. 2010;82(10):1694-700. doi:10.1002/jmv.21877. [PubMed:20827767] 